Jurnal Sain Veteriner, Vol. 39. No. 2. Agustus 2021, Hal. 151-160

DOI: $10.22146 /$ jsv.60557

ISSN 0126-0421 (Print), ISSN 2407-3733 (Online)

Tersedia online di https://jurnal.ugm.ac.id/jsv

\title{
Identifikasi Molekuler Bakteri Staphylococcus sp. dan Staphylococcus aureus Penyebab Mastitis Subklinis pada Ternak Kambing Perah
}

\section{Molecular Identification of Staphylococcus sp. and Staphylococcus aureus Causes of Subclinical Mastitis in Dairy Goats}

\author{
Clara Ajeng Artdita*, Fatkhanuddin Aziz, Nurulia Hidayah, Achmad Fauzi, \\ Triastuti Septi Wulandari, Reza Luthfi Hamid
}

\author{
Program Studi Teknologi Veteriner, Departemen Teknologi Hayati dan Veteriner, \\ Sekolah Vokasi, Universitas Gadjah Mada, Yogyakarta \\ "Email: clara.ajeng@ugm.ac.id
}

Naskah diterima: 13 Oktober 2020, direvisi: 30 Maret 2021, disetujui: 24 Juni 2021

\begin{abstract}
Mastitis is intra-mammary infection (IMI) of dairy animals. Subclinical mastitis is often associated with the incidence of mastitis in small ruminant farms such as Peranakan Etawah, Saanen and Sapera dairy goats. Genus Staphylococcus is known as one of the the main pathogen causing mastitis. This research aimed to identified Staphylococcus sp. and Staphylococcus aureus from collected isolates by PCR. Twenty six isolates used in this study were isolated from fresh milk goat samples (Peranakan Etawah, Saanen, and Sapera) from Kokap (Kulonprogo) and Turi (Sleman), Daerah Istimewa Yogyakarta and previous study. DNA templates were extracted and subjected for 23S rRNA gene of Staphylococcus sp., Staphylococcus aureus, and methicillin resistant Staphylococcus aureus (MRSA). A total of 12 isolates were identified as Staphylococcus sp. and 1 isolate was Staphylococcus aureus. In addition, the isolate identified by Staphylococcus aureus was not MRSA group.
\end{abstract}

Keywords: dairy goat; molecular identification; Staphylococcus aureus; Staphylococcus sp.; subclinical mastitis

\begin{abstract}
Abstrak
Mastitis merupakan radang pada glandula mammae (ambing) ternak perah. Mastitis tipe subklinis sering dikaitkan pada kejadian mastitis di peternakan ruminansia kecil seperti kambing perah (kambing Peranakan Etawah, Saanen, dan Sapera). Genus Staphylococcus diketahui merupakan salah satu patogen utama penyebab mastitis. Tujuan penelitian adalah mengidentifikasi bakteri Staphylococcus sp. dan Staphylococcus aureus dari koleksi isolat menggunakan teknik PCR. Dua puluh enam isolat yang digunakan pada penelitian ini berasal dari sampel susu kambing perah di daerah Kokap (Kulonprogo) dan Turi (Sleman), Daerah Istimewa Yogyakarta dan penelitian sebelumnya. Ekstraksi DNA dilakukan pada semua isolat dan digunakan untuk mendeteksi gen spesifik 23s rRNA Staphylococcus sp. dan Staphylococcus aureus, serta methicillin resistant Staphylococcus aureus (MRSA). Hasil PCR menunjukkan sebanyak 12 isolat teridentifikasi Staphylococcus sp. dan 1 isolat diantaranya adalah Staphylococcus aureus. Satu isolat teridentifikasi Staphylococcus aureus tersebut bukan merupakan kelompok bakteri MRSA.
\end{abstract}

Kata kunci: identifikasi molekuler; kambing perah; mastitis subklinis; Staphylococcus aureus; Staphylococcus $s p$. 


\section{Pendahuluan}

Jenis ternak perah yang dibudidayakan untuk produksi susu adalah kambing, domba (ruminansia kecil) serta sapi dan kerbau (ruminansia besar) (Bergonier et al., 2003). Kambing saat ini banyak dibudidayakan sebagai ternak perah di Indonesia dan sangat berpotensi dalam peningkatan pendapatan masayarakat (Balitbangtan, 2020). Jenis kambing perah unggul yang mulai dibudidayakan di Indonesia adalah kambing Peranakan Etawah, kambing Saanen, dan kambing Sapera atau Basari (merupakan persilangan antara kambing Saanen dengan kambing PE) (Anonim, 2020). Potensi besar peternakan kambing perah salah satunya adalah berkaitan dengan harga jual susu kambing segar yang tinggi, yaitu sekitar $R p$ 7,000,per $200 \mathrm{~mL}$ atau Rp 30,000,- sampai dengan Rp 50,000,- per liter (Aji, 2020; Ridlo, 2020) sehingga dapat meningkatkan kesejahteraan peternak kambing perah (Ridlo, 2020).

Menurut Standar Nasional Indonesia (2011), susu segar merupakan cairan yang berasal dari ambing ternak perah yang sehat, diperoleh dengan metode pemerahan yang benar, dan masih memiliki kandungan alami yang utuh tanpa penambahan suatu bahan apapun, serta belum mendapatkan perlakuan apapun selain pendinginan. Salah satu potensi bahaya yang terdapat di dalam susu maupun produk olahannya adalah adanya kontaminasi bakteri (bahaya mikrobiologis), terutama oleh bakteri patogen (Owusu-Kwarteng et al., 2020) yang salah satunya disebabkan adanya kasus mastitis pada ternak perah.

Mastitis merupakan radang pada glandula mammae yang disebabkan oleh infeksi patogen (Ruegg, 2017). Tipe mastitis subklinis (tanpa gejala) sering ditemukan pada ternak perah kambing perah dengan jumlah sel somatic $(\mathrm{JSS}) \geq 500 \times 10^{3}$ cells $/ \mathrm{ml}$ (Kiossis et al., 2007; Rupp et al., 2019) dan JSS ini lebih tinggi pada kambing dibandingkan sapi maupun domba (Rupp et al., 2019). Patogen yang ditemukan pada kasus mastitis ruminasia kecil sebagian besar disebabkan oleh kelompok bakteri Gram positif (Staphylococcus aureus, Staphylococcus epidermidis, Streptococcus agalactiae, Streptococcus dysagalactiae, Streptococcus uberis,
Enterobacteriaceae) (Zadoks et al., 2011) dan Gram negatif (Klebsiella pneumoniae (Artdita et al., 2018), Klebsiella oxytoca, Klebsiella varicola dan kelompok Coliforms seperti Escherichia coli) (Munoz et al., 2008; Zadoks et al., 2011).

Kasus mastitis pada kambing perah yang paling sering terjadi adalah kejadian mastitis subklinis dengan prevalensi sekitar 15-40\% (Contreras, 2007; Kiossis et al., 2007; Omar and Mat-Kamir, 2018). Kondisi mastitis subklinis ditandai dengan adanya peningkatan jumlah sel somatik (JSS) dalam susu dimana kondisi ini dapat digunakan sebagai deteksi awal kejadian mastitis dengan menggunakan reagen california mastitis test (CMT). Status kambing positif mastitis adalah apabila hasil uji CMT menunjukkan positif $2(++)$ atau positif $3(+++)$, selanjutnya status mastitis ini diteguhkan dengan pengujian laboratoris berupa pemeriksaan bakteri patogen yang mengontaminasi susu mastitis tersebut (McDougall et al., 2002; Persson and Olofsson, 2011). Salah satu metode identifikasi molekuler patogen penyebab mastitis adalah metode Polymerase Chain Reaction (PCR) (Zadoks and Watts, 2009; Wyder et al., 2011). Boss et al. (2011) dan Hiitiö et al., (2015) juga telah mengembangkan metode identifikasi molekuler ini dengan metode real time quantitative PCR. Metode PCR memiliki sensitivitas dan spesivitas yang tinggi. Penelitian ini bertujuan mengidentifikasi bakteri Staphylococcus sp. dan Staphylococcus aureus penyebab mastitis subklinis pada kambing perah dengan menggunakan metode PCR.

\section{Materi dan Metode}

\section{Isolat bakteri}

Sebanyak 26 isolat bakteri Gram positif diperoleh dari gabungan sampel penelitian sebelumnya (Artdita et al., 2020a) dan sampel lain dari susu kambing perah jenis PE, Sapera, dan Saanen yang mengalami mastitis subklinis. Isolat bakteri tersebut diambil dari gabungan sampel susu segar kambing perah yang berasal dari Kokap (Kulonprogo) dan Turi (Sleman), Daerah Istimewa Yogyakarta. Isolat bakteri yang digunakan ini telah dilakukan identifikasi mikrobiologi (uji biokimiawi) meliputi 
kemampuan tumbuh pada media mannitol salt agar (MSA), positif uji katalase dan koagulase, dan pada pewarnaan Gram sel berwarna ungu dengan bentuk sel adalah coccus. Kontrol positif Staphylococus aureus menggunakan isolat dengan kode American Type Culture Cell (ATCC) 25923 milik Balai Besar Veteriner Kementerian Pertanian Republik Indonesia dan isolat Methicillin Resistant Staphylococcus aureus (MRSA) dengan kode MRSA 1629 yang diperoleh dari Bagian Mikrobiologi Fakultas Kedokteran Universitas Gadjah Mada sebagai kontrol positif gen penyandi resistensi terhadap antibiotik Methycillin.

\section{Ekstraksi DNA}

Ekstraksi DNA bakteri dilakukan sesuai protokol Gsync DNA Extraction Kit (Geneaid ${ }^{\circledR}$ ) dengan modifikasi pada preparasi sampel. Sebanyak $1 \mathrm{~mL}$ isolat dari media ToddHewitt Broth (THB) yang telah diinkubasikan pada suhu $37^{\circ} \mathrm{C}$ selama 24 jam, disentrifugasi 13.000 RPM selama 5 menit. Supernatan dibuang dan ditambahkan $200 \mu \mathrm{L}$ Gram+ buffer (yang telah ditambahkan $25 \mu \mathrm{L}$ Lysozyme (0.8 mg final concentration)), kemudian diinkubasi pada suhu $37^{\circ} \mathrm{C}$ selama 30 menit hingga 2 jam. Proteinase- $K(20 \mathrm{mg} / \mathrm{ml})$ ditambahkan sebanyak $20 \mu \mathrm{L}$, di vortex dan diinkubasi pada suhu $55^{\circ} \mathrm{C}$ selama 2-12 jam (overnight). Campuran kemudian disentrifugasi (mode pulse), supernatan dipindahkan ke tube 1,5 $\mathrm{mL}$ steril, ditambahkan $200 \mu \mathrm{L}$ GB buffer dan divortex, lalu diinkubasi pada suhu $70^{\circ} \mathrm{C}$ selama $10-30$ menit, dan divortex tiap 3 menit. Selanjutnya sampel ditambahkan $200 \mu \mathrm{L}$ ethanol absolut (dingin), lalu divortex dan disentrifus mode pulse. Seluruh larutan campuran dipindah ke dalam GS column, kemudian disentrifus 12.000 rpm selama 1 menit. Kontaminan DNA dicuci menggunakan $400 \mu \mathrm{L}$ W1 buffer dan $600 \mu \mathrm{L}$ wash buffer, disentrifugasi dengan kecepatan $12.000 \mathrm{rpm}$ selama 1 menit. Sebelum proses elusi DNA, GS column disentrifugasi dengan kecepatan 12.000 rpm selama 3 menit, kemudian DNA di elusi dengan $100 \mu \mathrm{L}$ elution buffer dengan kecepatan $12.000 \mathrm{rpm}$ selama 1 menit. Sampel DNA kemudian disimpan pada freezer $-20^{\circ} \mathrm{C}$.

\section{Amplifikasi gen spesifik}

Identifikasi molekuler gen spesifik $23 \mathrm{~s}$ rRNA Staphylococcus sp, 23s rRNA S.aureus, dan mecA dilakukan dengan metode PCR menggunakan primer dan program pada tabel 1 . Campuran PCR sebanyak $25 \mu \mathrm{l}$ terdiri atas $2 \mu \mathrm{l}$ primer $1(10 \mathrm{pmol} / \mu \mathrm{l})\left(\mathrm{IDT}^{\circledR}\right), 2 \mu \mathrm{l}$ primer $2(10$ $\mathrm{pmol} / \mu \mathrm{l})\left(\mathrm{IDT}^{\circledR}\right), 12,5 \mu \mathrm{l} \mathrm{PCR} \operatorname{mix}\left(\mathrm{SMOBIO}^{\circledR}\right)$, $6.5 \mu \mathrm{l} \mathrm{ddH}_{2} \mathrm{O}$ molecular grade 2 (SIGMA ALDRICH $^{\circledR}$ ) dan $2 \mu$ l sampel DNA. Campuran kemudian disentrifugasi selama beberapa detik dan dimasukkan ke dalam mesin thermal cycler $\left(\right.$ Eppendorf $\left.^{\circledR}\right)$. Amplikon dielektroforesis pada agarose $2 \%$ dan $2 \mu$ DNA staining (1st

Tabel 1. Sekuens primer yang digunakan untuk proses amplifikasi gen Staphylococcus sp. dan Staphylococcus aureus.

\begin{tabular}{|c|c|c|c|c|}
\hline $\begin{array}{l}\text { Target gen } \\
\text { (amplikon) }\end{array}$ & Sekuens primer & $\begin{array}{c}\text { Suhu } \\
\text { annealing }\end{array}$ & $\begin{array}{l}\text { Program } \\
\text { PCR* }\end{array}$ & Referensi \\
\hline $\begin{array}{l}\text { 23s rRNA Staphylococcus sp. } \\
\text { (499 bp) }\end{array}$ & $\begin{array}{l}\text { 5' AGC TGT GGA TTG TCC TTT GG 3' } \\
\text { 3' TCG CTC GCT CAC CTT AGA AT 5' }\end{array}$ & $56^{\circ} \mathrm{C}$ & 1 & $\begin{array}{l}\text { Cremonesi et al., } \\
2005\end{array}$ \\
\hline $\begin{array}{l}\text { 23s rRNA Staphylococcus aureus } \\
(1250 \mathrm{bp})\end{array}$ & $\begin{array}{l}\text { 5'ACG GAG TTA CAA AGG ACG AC 3' } \\
\text { 3'AGC TCA GCC TTA ACG AGT AC 5' }\end{array}$ & $64^{\circ} \mathrm{C}$ & 2 & $\begin{array}{l}\text { Straub et al., } \\
1999\end{array}$ \\
\hline $\begin{array}{l}\text { mecA } \\
(532 \text { bp) }\end{array}$ & $\begin{array}{l}\text { 5' AAAATCGATGGTAAAGGTTGGC 3' } \\
\text { 3' AGTTCTGCAGTACCGGATTTGC 5' }\end{array}$ & $55^{\circ} \mathrm{C}$ & 3 & $\begin{array}{l}\text { Strommenger } \\
\text { et al., } 2003\end{array}$ \\
\hline
\end{tabular}

\footnotetext{
* Program PCR:
}

Pre-denaturasi: $94^{\circ} \mathrm{C} 120$ detik, denaturasi: $94^{\circ} \mathrm{C} 30$ detik, annealing : $56^{\circ} \mathrm{C} 30$ detik, elongasi : $72^{\circ} \mathrm{C} 20$ detik, final elongasi: $72^{\circ} \mathrm{C} 7$ menit (30 siklus)

Pre-denaturasi: $94^{\circ} \mathrm{C} 120$ detik, denaturasi: $94^{\circ} \mathrm{C} 30$ detik, annealing : $64^{\circ} \mathrm{C} 30$ detik, elongasi : $72^{\circ} \mathrm{C} 45$ detik, final elongasi: $72^{\circ} \mathrm{C} 7$ menit (35 siklus)

Pre-denaturasi: $94^{\circ} \mathrm{C} 120$ detik, denaturasi: $94^{\circ} \mathrm{C} 30$ detik, annealing : $55^{\circ} \mathrm{C} 30$ detik, elongasi : $72^{\circ} \mathrm{C} 30$ detik, final elongasi: $72^{\circ} \mathrm{C} 7$ menit (35 siklus) 
BASE $^{\circledR}$ ), selanjutnya divisualisasi dengan $U V$ transluminator, dibandingkan dengan kontrol + , kontrol -, dan penanda (marker atau ladder) 100 bp DNA Ladder $\left(\right.$ Geneaid $^{\circledR}$ ) atau $1 \mathrm{~kb} D N A$ Ladder (HyperLadder $\left.{ }^{\circledR}\right)$.

\section{Hasil dan Pembahasan}

Standar diagnosa terhadap kejadian mastitis pada ternak perah ruminansia kecil adalah pemeriksaan bakteriologi dari susu yang dihasilkan ternak perah tersebut. Hasil pemeriksaan fenotipik dari sampel susu mastitis tersaji ada Tabel 2. Sebanyak 18 isolat bakteri asal Kokap, Kulonprogo menggunakan data hasil penelitian sebelumnya (Artdita et al., $2020^{a}$ ) dan 8 isolat bakteri diperoleh dari susu kambing perah dengan kondisi mastitis yang diambil dari peternakan kambing perah di Turi, Sleman.

Kasus mastitis oleh infeksi bakteri pada kambing perah biasanya terjadi karena proses pemerahan yang kurang memperhatikan kebersihan, hal tersebut merupakan kondisi potensial transmisi bakteri Gram positif, khususnya genus Staphylococcus (Olechnowicz and Jaśkowski, 2014). Penelitian sebelumnya (Artdita et al., 2020a), memberikan hasil deteksi bakteri menggunakan metode uji biokimiawi (berdasarkan fenotipe) (Tabel 2). Pada penelitian tersebut, diperoleh hasil bahwa isolat bakteri tersebut termasuk ke dalam genus Staphylococcus. Genus ini merupakan kelompok bakteri Gram positif dengan bentuk sel adalah coccus dan dapat tumbuh pada media MSA yang memiliki kadar garam 7,5\% dengan komponen utama adalah mannitol (Olechnowicz and Jaśkowski, 2014). Beberapa isolat tersebut juga menunjukkan morfologi koloni putih kekuningan dengan atau tanpa memiliki kemampuan menghemolisa darah domba pada plat agar darah (PAD), memberikan hasil positif pada uji katalase, sedangkan pada uji koagulase memberikan hasil positif dan negatif pada beberapa isolat. Hasil dari 26 isolat bakteri Gram positif diperoleh dari gabungan sampel penelitian sebelumnya (Artdita et al., 2020a) dan sampel lain dari susu kambing perah jenis PE, Sapera, dan Saanen yang tumbuh pada media mannitol salt agar (MSA), positif uji katalase dan koagulase, serta bentuk sel adalah coccus tersebut mengarah pada genus Staphylococcus (Quinn et al., 2004; Forbes et al., 2007; Todar, 2008). Meskipun hasil uji mikrobiologi menunjukkan ciri umum Staphylococcus sp. atau spesies tertentu, namun peneguhan identifikasi molekuler Staphylococcus sp. dan Staphylococcus aureus penyebab mastitis dari isolat bakteri Gram positif tersebut perlu dilakukan. Hal ini dikarenakan adanya kesamaan karakter fenotipe bakteri sehingga sangat sulit menentukan spesiesnya. Oleh karena itu, perlu adanya suatu metode deteksi yang digunakan untuk menentukan tingkat spesies (genotyping) dengan metode identifikasi dengan menggunakan PCR (Zadoks and Watts, 2009; Wyder et al., 2011).

Metode ekstraksi DNA yang digunakan adalah spin column system. Dash et al. (2020) menjelaskan bahwa pemilihan metode ekstraksi ini memberikan keuntungan dari sisi kualitas DNA yang dihasilkan dan praktis. Tahapan metode ini meliputi tahapan lisis, DNA binding, pencucian, dan elusi. Selama tahap lisis, sel akan lisis dan mengeluarkan asam nukleat ke cairan reagen (Quigley et al., 2012; Dash et al., 2020). Enzim, seperti proteinase-K dan lysozyme (Parayre et al. 2007), dapat melisiskan sel bakteri

Tabel 2. Asal sampel isolat yang digunakan dalam pengujian genotipik

\begin{tabular}{|c|c|c|c|c|c|}
\hline Asal sampel awal & Jumlah Isolat & Pewarnaan Gram & MSA & $\begin{array}{c}\text { Uji } \\
\text { Katalase } \\
\end{array}$ & $\begin{array}{c}\text { Uji } \\
\text { Koagulase }\end{array}$ \\
\hline $\begin{array}{c}\text { Kokap, } \\
\text { Kulon Progo* }\end{array}$ & 10 & Ungu, bentuk sel coccus &,+ fermented & + & + \\
\hline $\begin{array}{c}\text { Kokap, } \\
\text { Kulon Progo* }\end{array}$ & 8 & Ungu, bentuk sel coccus &,+ non-fermented & + & - \\
\hline $\begin{array}{l}\text { Turi, } \\
\text { Sleman }\end{array}$ & 8 & Ungu, bentuk sel coccus &,+ non-fermented & + & - \\
\hline
\end{tabular}

*Artdita et al., $2020^{\text {a }}$ 
Gram positif (Quigley et al., 2012). Pada tahap DNA binding, adanya reagen DNA binding (ethanol), $\mathrm{pH}$ yang optimal dan sentrifugasi, maka DNA akan "terikat" di membran silika yang ada pada spin column (Dash et al., 2020). Komponen utama membran silika adalah diethylaminoethanol (DEAE) dan silika ini bekerja seperti prinsip afinitas kromatografi, dengan $\mathrm{pH}$ yang cocok, penambahan ion $\mathrm{H}^{+}$ pada column, dan sentrifugasi, maka silika akan menjadi bermuatan positif. Hal ini menyebabkan DNA yang bermuatan negatif dapat "terikat" di membran silika, sedangkan debris-debris yang lain akan melewati membran silika pada saat tahap pencucian dilakukan (Pirondini et al., 2010; Dash et al., 2020). Pada tahap elusi, buffer elusi akan meluruhkan DNA yang "terikat" di membran silika agar berpindah ke tube yang terpasang di bawah spin column (Dash et al., 2020).

Identifikasi dengan metode PCR dilakukan dengan tahapan: identifikasi Staphyococcus sp. dan Staphylococus aureus. Sampel yang ter- identifikasi Staphylococus aureus akan dilanjutkan dengan identifikasi bakteri yang resisten terhadap Methicillin (MRSA) dengan target gen $m e c A$. Hasil penelitian ini menunjukkan bahwa dari 26 sampel isolat bakteri Gram positif, teridentifikasi 12 isolat Staphyococcus sp. dan 1 isolat Staphylococus aureus. Target gen yang digunakan pada penelitian ini adalah 23s rRNA. Gen $23 s$ rRNA merupakan conserved region (urutan basa nukleotida pada 23S rRNA sangat identik dan spesifik) sehingga dapat digunakan untuk identifikasi genus maupun spesies (Doris et al., 2015). Identifikasi Staphylococcus sp. mengacu pada Cremonesi et al. (2005) dengan panjang amplikon 499 bp, sedangkan untuk Staphylococus aureus mengacu pada Straub et al. (1999) dengan panjang amplikon $1250 \mathrm{bp}$. Hasil band yang muncul selanjutnya diamati ukurannya terhadap ladder yang digunakan (untuk Staphylococcus sp. menggunakan ladder 100 bp dan untuk Staphylococus aureus menggunakan ladder $1.000 \mathrm{bp)}$ dan dibandingkan dengan kontrol positif. Sampel yang teridentifi-

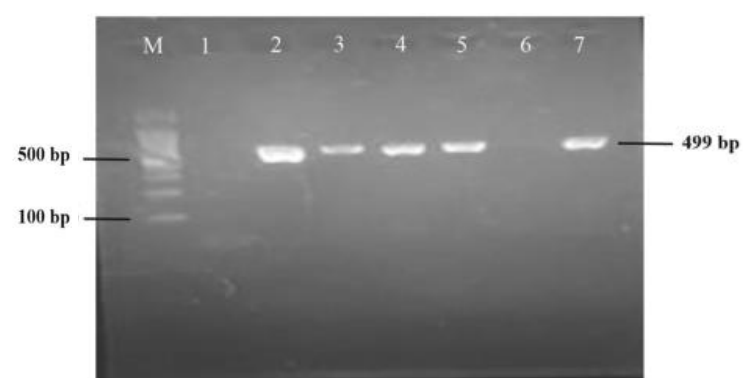

$1(\mathrm{~b})$

Gambar 1. Hasil elektroforesis DNA terhadap gen 23s rRNA (Staphylococcus sp.) dengan ukuran amplikon 499 bp menggunakan gel agarose (Ket. 2(a): M: Marker/Ladder; 1:Kontrol -; 2: Kontrol +; sumuran 3-8: sampel (sumuran 3,4,5,7,8 muncul band pada ukuran 499bp dan sumuran 6 tidak muncul band); 2(b): M: Marker/Ladder; 1:Kontrol -; 2: Kontrol +; sumuran 3-8: sampel (sumuran 3,4,5,7 muncul band pada ukuran 499bp dan sumuran 6 tidak muncul band).

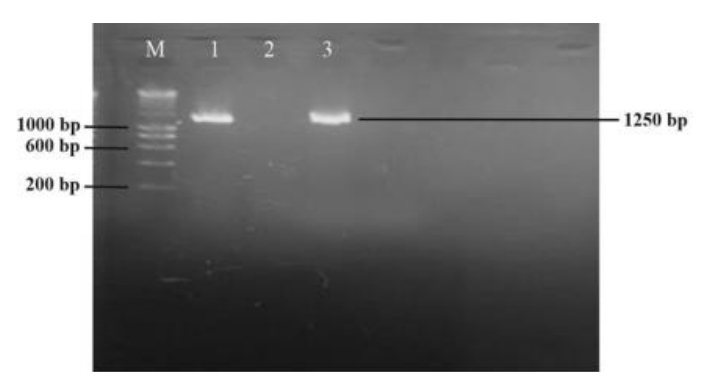

2(a)

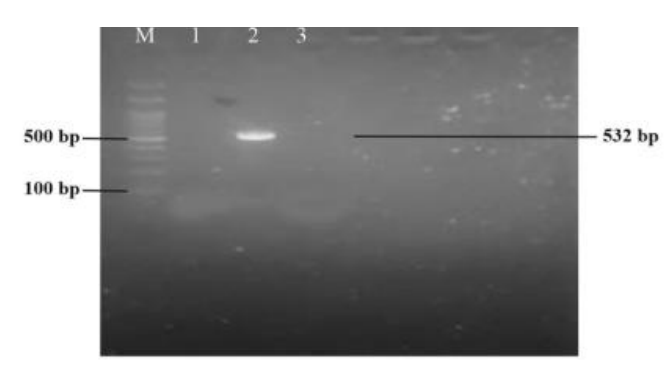

2(b) 2

Gambar 2 (a). Hasil elektroforesis DNA terhadap gen 23 s rRNA (Staphylococcus aureus) dengan ukuran amplikon 1.250 bp menggunakan gel agarose (Ket. M: Marker/Ladder; 1:Kontrol +; 2: Kontrol -; 3: sampel yang muncul band); 3(b). Hasil elektroforesis DNA MRSA dengan ukuran amplikon 532 bp menggunakan gel agarose (Ket. M: Marker/Ladder; 1:Kontrol -; 2: Kontrol +; 3: sampel yang tidak muncul band). 
kasi Staphylococcus aureus, dilanjutkan dengan deteksi terhadap gen mecA. Gen ini merupakan gen spesifik spesies Staphylococcus aureus yang termasuk ke dalam golongan MRSA (Cremonesi et al., 2005).

Hasil elektroforesis DNA Staphylococcus sp. (Gambar 1) menunjukkan bahwa sampel terdeteksi sebagai Staphylococcus sp. (sumuran no 3, 4, 5, 7, 8 pada Gambar 1(a) dan sumuran no 3, 4, 5, 7 pada Gambar 1(b)) dengan ukuran produk PCR 499 bp (Cremonesi et al., 2005) dibandingkan dengan kontrol positif ATCC (sumuran no 2). Windria et al. (2016) dan Aziz et al. (2020) menggunakan desain primer Cremonesi et al. (2005) untuk mendeteksi keberadaan gen 23s rRNA Staphylococcus sp. dari sampel susu kambing PE. Berdasar Gambar 2(a) diketahui bahwa terdapat 1 sampel merupakan Staphylococcus aureus dan tidak termasuk ke dalam golongan MRSA (Gambar 2b). Contreras et al., (2007) dan Virdis et al. (2010) menyebutkan bahwa beberapa patogen bertanggung jawab terhadap adanya infeksi mastitis pada ruminansia kecil, namun Staphylococcus sp. merupakan patogen yang paling banyak dijumpai pada kasus mastitis pada ruminansia kecil. Senada dengan Contreras et al., (2007) dan Virdis et al. (2010), Aziz et al. (2020) menyebutkan bahwa Staphylococcus sp. juga mendominasi hingga 61\% kejadian mastitis kambing Peranakan Etawah dan Staphylococcus aureus hanya sekitar 1.6\%. Zhao et al. (2015) menyebutkan kejadian mastitis subkinis di peternakan kambing di China, didominasi oleh coagulase-negative staphylococci (CNS) (59,52\%) sedangkan infeksi akibat Staphylococcus aureus hanya sebesar 15,24\%. Kasus mastitis pada peternakan ruminansia kecil paling banyak disebabkan oleh CNS yang menyebabkan penurunan produksi susu (Silva et al., 2004; Leitner et al., 2008; Ozenc et al., 2011). Prevalensi kejadian mastitis subklinis pada kambing perah dikarenakan infeksi CNS adalah 60\% sampai dengan $80.7 \%$ (McDougall et al., 2002; Silva et al., 2004; Hall and Rycroft, 2007), sedangkan pada domba perah adalah 4548\% (Spanu et al., 2011).

Staphylococcus aureus dapat diinokulasi dari sampel susu ternak perah ruminansia kecil yang mengalami kasus mastitis subklinis (Mishra et al., 2014). Kejadian mastitis akibat
Staphylococcus aureus ini mampu menginduksi produksi sel somatik yang jauh lebih tinggi daripada infeksi yang disebabkan oleh CNS. Hal tersebut menjadi pertimbangan bahwa Staphylococcus aureus sebagai salah satu patogen utama penyebab kejadian mastitis pada ruminansia kecil (McDougall et al., 2002; Contreras et al., 2007; Mishra et al., 2014). Contreras et al. (2007) dan Reinard et al. (2018) menyebutkan bahwa banyak kasus mastitis yang disebabkan oleh infeksi bakteri Staphylococcus aureus merupakan tipe mastitis klinis. Lebih lanjut, infeksi akibat Staphylococcus aureus ini juga tidak jarang hingga menyebabkan kondisi gangrene pada ambing ternak (Reinard et al., 2018). Patogen lain yang berperan sebagai penyebab mastitis pada ruminansia kecil selain dari genus Staphylococcus adalah Streptococcus sp., Enterobacteriaceae, Mannheimia haemolytica (Bergonier and Berthelot, 2003; Bergonier et al., 2003; Contreras et al., 2007; Mishra et al., 2018), Pseudomonas aeruginosa, Corynebacteria (Bergonier and Berthelot, 2003; Contreras et al., 2007), Bacillus spp., Arcanobacterium pyogenes (Mishra et al., 2018), dan fungi (Aspergillus fumigatus) dengan tingkat kejadiannya rendah (Bergonier and Berthelot, 2003; Contreras et al., 2007).

Proses pemerahan menjadi proses yang penting karena dapat menyebabkan terjadinya infeksi pada ambing ruminansia kecil, khususnya infeksi dari genus Staphylococcus (Bergonier and Berthelot, 2003; Olechnowicz and Jaśkowski, 2014). Pencegahan mastitis pada kambing perah dapat dilakukan dengan cara pemerahan yang rutin dan aseptis, salah satunya dengan penerapan teat dipping setelah pemerahan (Indarwati et al., 2015), baik dengan metode sprayer (Artdita et al., 2020 ) maupun pencelupan (Priono et al., 2016). Oleh karena itu, peternak kambing perah perlu diberikan edukasi dan pendampingan agar memahami pentingnya good dairy farming practices (GDFP), salah satunya adalah dengan teat dipping setelah dilakukan pemerahan (Indarwati et al., 2015; Artdita et al., 2020b).

\section{Kesimpulan}

Identifikasi molekuler isolat bakteri penyebab mastitis subklinis pada kambing perah 
adalah sebanyak 12 isolat bakteri merupakan Staphylococcus sp. dan 1 isolat merupakan Staphylococcus aureus. Bakteri yang teridentifikasi Staphylococcus aureus ini bukan termasuk MRSA.

\section{Daftar Pustaka}

Aji, D.U. (2020). Tingkatkan Imun, Susu Kambing di Kudus Laris Manis Diserbu Pembeli. https://news.detik.com/beritajawa-tengah/d-5166102/tingkatkanimun-susu-kambing-di-kudus-larismanis-diserbu-pembeli (accessed : 12 Oktober 2020)

Anonim. (2020). Jenis-Jenis Kambing Perah Unggul. https://www.pertanianku. com/jenis-jenis-kambing-perahunggul/\#: : text=Pertanianku\%20 $\%$ E $2 \% 80 \% 94 \% 20 \mathrm{Ag}$ a r \% 20 $\mathrm{men}$ ghas i $1 \mathrm{kan} \% 20 \mathrm{sus} \mathrm{u} \% 20$ kambing,3\%20jenis\%20kambing\%20 perah\%20tersebut. (accessed : 05 Oktober 2020)

Artdita, C.A., Andityas, M., Prihanani, N.I., and Budiyanto, Y.W. (2020 $)$. Deteksi Bakteri Penyebab Mastitis Subklinis pada Kambing Peranakan Etawah di Kokap, Kulon Progo, Daerah Istimewa Yogyakarta. Jurnal Sain Veteriner. 38(1):37-44.

Artdita, C.A., Andityas, M., Martien, R., Setyaningrum, MAE., and Fauzi, A. $\left(2020^{b}\right)$. Pendampingan Kegiatan Dipping Puting pada Ternak Kambing Perah di Desa Turgo, Turi, Sleman, Yogyakarta. Sarwahita: Jurnal Pengabdian kepada Masyarakat. 17:1-7.

Artdita, C.A., Lestari, F.B., Fauzi, A., Tanzila, E.P.A., (2018). Klebsiella pneumoniae Isolated from Subclinical Mastitis Milk of Etawah Crossbreed Goat. Jurnal Sain Veteriner. 36(2):238-245.

Aziz, F., Lestari, B.L., Nuraida S., Purwati, E., and Salasia, S.I.O. (2020). Deteksi Staphylococcus aureus dan Staphylococcus sp. secara Langsung dari Susu Segar Kambing Peranakan Etawa dengan Polymerase Chain Reaction
(PCR). Jurnal Sain Veteriner. 38(2):168174.

Badan Standardisasi Nasional [BSN]. (2011). Susu Segar Bagian 1: Sapi. SNI 01-31412011. Badan Standardisasi Nasional. Jakarta.

Bergonier D., de Crémoux R., Rupp R., Lagriffoul G., and Berthelot X. (2003). Mastitis of dairy small ruminants. Vet. Res. 34:689-716.

Boss, R., Naskova, J., Steiner, A., and Graber, H.U. (2011). Mastitis diagnostics: Quantitative PCR for Staphylococcus aureus genotype B in bulk tank milk. Journal of Dairy Science. 94(1):128-137.

Contreras, A., Sierra, D., Sánchez, A., Corrales, J.C., Marco, J.C., Paape, M.J. and Gonzalo, C. (2007). Mastitis in small ruminants. Small Ruminant Research. 68:145-15.

Cremonesi, P., Luzzana, M., Brasca, M., Morandi, S., Lodi, R., Vimercati, C., and Castiglioni, B. (2005). Development of a multiplex PCR assay for the identification of Staphylococcus aureus enterotoxigenic strains isolated from milk and dairy products. Molecular and cellular probes. 19(5): 299-305.

Dash, H. R., Shrivastava, P., and Das, S. (2020). Isolation of DNA by Using Column-Based Extraction System. In Principles and Practices of DNA Analysis: A Laboratory Manual for Forensic DNA Typing. Humana, New York, NY.

Doris, S.M., Smith, D.R., Beamesderfer, J.N., Raphael B.J., Nathanson, J.A., and Gerbi, S.A. (2015). Universal and domainspecific sequences in 23S-28S ribosomal RNA identified by computational phylogenetics. RNA. 21(10): 1719-1730.

Forbes, BA., Shamn, DF., and Weisffeld, AS. (2007). Bailey and Scott's Diagnostic Microbiology. $12^{\text {th }}$ edition. USA: Mosby.

Hall, S.M. and Rycroft, A.N. (2007). Causative organisms and somatic cell counts in subclinical intramammary infections in milking goats in the UK. Vet Rec.160 (1) : 19-22. 
Hiitiö, H., Riva, R., Autio, T., Pohjanvirta, T., Holopainen, J., Pyörälä, S., and Pelkonen, S. (2015). Performance of a real-time PCR assay in routine bovine mastitisdiagnostics compared with indepth conventional culture. Journal of Dairy Research. 82(02):1-9.

Indarwati, R., Herawati, and Arisoesilaningsih, E. (2015). Strategic planning to develop good dairy farming practices in Smallholder Dairy Farms in Batu City, East Java. J-PAL. 6(2):163-170.

Kiossis, E., Brozos, C. N., Petridou, E., and Boscos, C. (2007). Program for the control of subclinical mastitis in dairy Chios breed ewes during lactation. Small Ruminant Res. 73:194-199.

Leitner, G., Silanikove, N., and Merin, U. (2008). Estimate of milk and curd yield loss of sheep and goats with intrammamary infection and its relation to somatic cell count. Small Ruminant Res. 74:221-225.

McDougall, S., Pankey, W., Delaney, C., Barlow, J., Murdough, P.A., and Scruton, D. (2002). Prevalence and incidence of subclinical mastitis in goats and dairy ewes in Vermont USA. Small Rumin Res. 46(2-3) : 115-121.

Mishra, AK., Sharma, N., Kumar, A., Kumar, N., Gundallahalli, BMR., Kumar, S., and Kumar, V. (2014). Isolation, characterization and therapeutic potential assessment of bacteriophages virulent to Staphylococcus aureus associated with goat mastitis. Iran. J. Vet. Res. 15(4):320325 .

Mishra, AK., Sharma, N., Singh, DD., Gururaj. K., Abhishek, Kumar, V., Sharma, DK. (2018) Prevalence and bacterial etiology of subclinical mastitis in goats reared in organized farms, Veterinary World, 11(1): 20-24.

Munoz, M.A., Bennett, G.J., Ahlström, C., Griffiths, H.M., Schukken, Y.H., and Zadoks, R.N. (2008). Cleanliness scores as indicator of Klebsiella exposure in dairy cows. J Dairy Sci. 91(10):3908 -16.
Olechnowicz, J. and Jaśkowski, J.M. (2014). Mastitis in Small Ruminant. Med. Weter. 70(2):67-72.

Omar, S. and Mat-Kamir, N.F., (2018). Isolation and identification of common bacteria causing subclinical mastitis in dairy goats. Int. Food Res. J. 25(4):1668-1674.

Owusu-Kwarteng, J., Akabanda, F., Agyei, D., and Jespersen, L. (2020). Microbial Safety of Milk Production and Fermented Dairy Products in Africa. Microorganism. 8(752):1-24.

Ozenc, E., Seker, E., Baki Acar, D., Birdane, M. K., Darbaz, I., and Dogan, N. (2011). The importance of Staphylococci and threshold value of somatic cell count for diagnosis of sub-clinical mastitis in Pirlak sheep at mid-lactation. Reprod. Dom. Anim. 46:970-974.

Parayre, S., Falentin, H., Madec, M.N., Sivieri, K., Le Dizes, A.S., Sohier, D. and Lortal, S. (2007). Easy DNA extraction method and optimisation of PCR-Temporal Temperature Gel Electrophoresis to identify the predominant high and low GC-content bacteria from dairy products. J Microbiol Methods. 69, 431-441.

Persson, Y. and Olofsson, I. (2011). Direct and indirect measurement of somatic cell count as indicator of intramammary infection in dairy goats. Acta Vet Scand. 53(15) : 1-5.

Pirondini, A., Bonas, U., Maestri, E., Visioli, G., Marmiroli, M. and Marmiroli, N. (2010). Yield and amplificability of different DNA extraction procedures for traceability in the dairy food chain. Food Control. 21, 663-668.

Priono, D., Kusumanti, E., and Harjanti, DW. (2016). Jumlah bakteri Staphylococcus aureus dan skor California Mastitis Test (CMT) pada susu kambing Peranakan Etawa akibat dipping ekstrak daun Babadotan (Ageratum conyzoides L.) Jurnal Ilmu-Ilmu Peternakan. 26(1):52-57.

Pusat Penelitian dan Pengembangan Peternakan Kementerian Pertanian (Balitbangtan). 
(2020). Kambing Perah Indonesia, Kambing Peranakan Etawah. http:// www.litbang.pertanian.go.id/infoteknologi/3979/ (accessed: 05 Oktober 2020).

Quigley, L., O’Sullivan, O., Beresford, TP., Paul Ross, R., Fitzgerald, GF., and Cotter, PD. (2012). A comparison of methods used to extract bacterial DNA from raw milk and raw milk cheese. Journal of Applied Microbiology. 113:96-105.

Quinn, P.J., Carter, M.E., Markey, B., dan Carter, G.R. (2004). Clinical Veterinary Microbiology. USA, Mosby.

Rainard, P., Gitton, C., Chaumeil, T., Fassier, T., Huau, C., Riou, M., Tosser-Klopp, G., Krupova, Z., Chaize, A., Gilbert, FB., Rupp, R., and Martin, P. (2018). Host factors determine the evolution of infection with Staphylococcus aureus to gangrenous mastitis in goats. Vet Res. 49:72.

Ridlo, M. (2020). Mereguk Susu Kambing Pegunungan Cilacap di Pagi hari Segar Menyehatkan. https://www.liputan6. com/regional/read/4297187/mereguksusu-kambing-pegunungan-cilacap-dipagi-hari-segar-menyehatkan (accessed : 12 Oktober 2020).

Ruegg, PL. (2017). A 100-Year Review: Mastitis detection, management, and prevention. $J$ Dairy Sci. 100(12):10381-10397.

Rupp, R., Huau, C., Caillat, H., Fassier, T., Bouvier, F., Pampouille, E., Clément, V., Palhière, I., Larroque, H., G.TosserKlopp, G., Jacquiet, P., and Rainard, P. (2019). Divergent selection on milk somatic cell count in goats improves udder health and milk quality with no effect on nematode resistance. Journal of Dairy Science. 102(6): 5242-5253.

Silva, E. R. da, Siqueira, A. P., Dias, Martins J. C., Barbosa, Ferreira, W. P., and da Silva N. (2004). Identification and in vitro antimicrobial susceptibility of Staphylococcus species isolated from goat mastitis in the Northeast of Brazil. Small Ruminant Res. 55:45-49.
Spanu C., Bergerb Y. M., Thomasc D. L., and Ruegg P. L. (2011). Impact of intramammary antimicrobial dry treatment and teat sanitation on somatic cell count and intramammary infection in dairy ewes. Small Ruminant Res. 97:139-145.

Straub, J. A., Hertel, C. and Hammes, W. P. (1999). A 23S rRNA-Targeted Polymerase Chain Reaction-Based System for Detection of Staphylococcus aureus in Meat Starter Cultures and Dairy Products. J. Food Prot. 62 (10):1150-1156.

Strommenger, B., Kettlitz, C., Werner, G., and Witte, W. (2003). Multiplex PCR assay for simultaneous detection of nine clinically relevant antibiotic resistance genes in Staphylococcus aureus. J. Clin. Microbiol. 41(9):4089-4094.

Todar, K. (2008). Staphylococcus aureus and Staphylococcal Disease; Todar's Online Textbook of Bacteriology. www.textbook of bacteriology.net.

Virdis, S., Scarano, C., Cossu, F., Spanu, V., Spanu, C., and de Santis, EPL. (2010) Antibiotic resistance in Staphylococcus aureus and coagulase negative Staphylococci isolated from goats with subclinical mastitis. Vet. Med. Int. 2010:517060.

Windria, S., Widianingrum, D. C., \& Salasia, S. I. O. (2016). Identification of Staphylococcus aureus and Coagulase Negative Staphylococci Isolates from Mastitis Milk of Etawa Crossbred Goat. Research Journal of Microbiology.11(1): 11.

Wyder, A.B., Boss, R., Naskova, J., Kaufmann, T., Steiner, A., and Graber, H.U. (2011). Streptococcus sp and related bacteria: their identification and their pathogenic potential for chronic mastitis - a molecular approach. Res. Vet. Sci. 91(3): 349-357.

Zadoks, R.N., Middleton, J.R., McDougall, S., Katholm, J., and Schukken, Y.H. (2011). Molecular epidemiology of mastitis pathogens of dairy cattle and comparative relevance to humans. J Mammary Gland Biol Neoplasia. 16: 357-372. 
Zadoks, R.N. and Watts, J.L. (2009). Species identification of coagulase-negativestaphylococci: genotyping is superior to phenotyping. Vet Microbiol. 134(1-2): 20-28.
Zhao, Y., Liu, H., Zhao, X., Gao, Y., Zhang, M., dan Chen, D. (2015). Prevalence and pathogens of subclinical mastitis in dairy goats in China. Trop Anim Health Prod. 47:429-435. 